\title{
Application of Lactococcus lactis subsp. lactis and cremoris as Starter Culture in the Colonial Cheese Production
}

\author{
Jéssica Barrionuevo Ressutte, Thainá Rodrigues Stella, Magali Soares dos Santos Pozza, \\ Grasiele Scaramal Madrona
}

Food engineering department, State University of Maringá, Colombo, Brazil

\author{
Received: Mar. 12, 2020 \\ Accepted: Apr. 6, 2020 \\ Published: Apr. 15, 2020
}

doi:10.5296/jas.v8i2.16660

URL: https://doi.org/10.5296/jas.v8i2.16660

\begin{abstract}
The addition of the starter culture composed of Lactococcus lactis subsp. lactis and Lactococcus lactis subsp. cremoris coming from two commercial brands was evaluated in Colonial cheese during the maturation period. The physiochemical parameters suggest an increase in lactic bacteria due to the reduction of $\mathrm{pH}$ and an increase in acidity; the starter culture did not influence the yields, moisture, ash, and instrumental color of the samples. The microbiological parameters show control of the growth of aerobic mesophiles compared to the control (without addition of the culture). As such, the use of evaluated cultures is a viable method for improving the quality of Colonial cheese.
\end{abstract}

Keywords: Acidification, fermentation, food security, lactic culture, microbial control, pasteurized milk

\section{Introduction}

The majority of artisanal cheeses produced in the south of Brazil is Colonial cheese. This type of cheese is made in small industries or properties, generally by the family of the farmer. Colonial cheese plays an important role in the economic life of many producers that have cheese production as a source of income. Milk, salt and coagulant are used in the processing. Traditionally, unpasteurized milk is used, due to its richer and more accentuated flavour provided by the native milk bacteria (Bánkuti et al., 2017).

On the other hand, there are many accounts of contamination by pathogenic bacteria in cheese produced by unpasteurized milk in Brazil, which is an important vehicle for disease transmission, causing economic losses and risks to public health. Even cheese from healthy animals can be contaminated, depending on the sanitation and hygiene measures taken during the milking, transportation, and storage (Bánkuti et al., 2017; Fava, Hernandes, Pinto, \& Schmidt, 2012). 
Furthermore, there is a global preoccupation with food security. For this reason, small cheese producers adopt strategies to avoid contamination of the product. Among the economically viable options, pasteurization is the most often applied, due to its low cost and effectiveness. However, this process eliminates not only the pathogenic bacteria in the milk, but also the bacteria responsible for the production of substances that provide the sensorial characteristics appreciated in Colonial cheese (Bánkuti et al., 2017; Vázquez-Velázquez, Salvador-Figueroa, Adriano-Anaya, Degyves-Córdova, \& Vázquez-Ovando, 2018).

In an attempt to make colonial cheese with characteristics similar to the original, the addition of lactic acid bacteria (LAB) as a starter culture in the processing of cheese made from pasteurized milk is a viable alternative. The LABs transform the lactose and the milk citrates into lactic acid, resulting in volatile compounds, providing desirable aroma and acid-fresh flavour. The production of antimicrobial compounds and the substrate competition are capable of inhibiting the growth of pathogenic microorganisms in cheese. Moreover, the addition of live cultures in products that go through a fermentation process can improve intestinal health and immunity in humans (Blaya, Barzideh, \& LaPointe, 2017; Favaro, Barretto Penna, \& Todorov, 2015; Masood, Qadir, Shirazi, \& Khan, 2011).

A starter culture can meet the basic criteria for use in cheese production, with satisfactory production of lactic acid, expected final characteristics of cheese, and the absence of microorganisms that can cause any damage to human health. Cultures extracted from cheeses using artisanal methods can have greater variations and risks of microbiological contamination than cultures tested in laboratories and sold commercially (Parente, Cogan, \& Powell, 2017).

Lactic acid bacteria can be found commercially in mixed form, in which there is a number of unknown strains, or in defined form, in which the number of strains is known. The subspecies of the Lactococcus lactis culture (Lactococcus lactis subsp. lactis and Lactococcus lactis subsp. cremoris) are predominantly used in cheese factories, due to their beneficial alterations in terms of flavour, smell, and texture. Moreover, the commercial strains produce bacteriocins capable of controlling pathogenic bacterial growth (Fernández, Alegría, Delgado, Martín, \& Mayo, 2011).

The subspecies Lactococcus lactis subsp. lactis is distinct from Lactococcus lactis subsp. cremoris due to five phenotypical criteria: ability to grow in $4 \% \mathrm{NaCl}, 40^{\circ} \mathrm{C}$ and $\mathrm{pH}$ above 9 , and the ability to diminish arginine and ferment maltose. In addition, Lactococcus lactis subsp. lactis is capable of assimilating the citrate with production of diacetyl. The bacteria Lactococcus lactis subsp. cremoris is preferred for use in some types of cheeses, due to its better proliferation in the milk and because it produces an agreeable aroma and fragrance (Fernández et al., 2011; Kelleher, Murphy, Mahony, \& Sinderen, 2015).

There is little research evaluating the use of starter cultures in the production of Colonial cheese. Therefore, this study attempts to evaluate the effect of the addition of the lyophilized commercial culture of Lactococcus lactis subsp. lactis and Lactococcus lactis subsp. cremoris on the physiochemical and microbiological aspects during the processing and maturation of Colonial cheese produced with unpasteurized and pasteurized milk. 


\section{Materials and Methods}

\subsection{Cheese Production}

The commercial starter cultures of the brands Choozit (ChoozitTM Ma Lyo 250 Dcu®, Danisco, France) and Docina (Docina Nutrição Ltd®, Brazil) named in this article K and M, respectively, containing the lyophilized microorganisms Lactococcus lactis subsp. lactis, and Lactococcus lactis subsp. cremoris were used for the cheese production. During processing, three variables were analyzed and different samples was produced: with pasteurized milk and the addition of lactic culture from the commercial brand $\mathrm{K}$ (T1), with pasteurized milk and the addition of lactic culture from the commercial brand M (T2), and with pasteurized milk without the addition of any lactic culture (T3).

The cheese processing followed the methodology proposed by Furtado and Lourenço (1994). The bovine milk (3.0\% fat) used in the production of the cheeses was collected from a rural property in the city of Maringá, PR, Brazil, with the necessary hygiene conditions and then transported and refrigerated until use. For the formulations T1, T2, and T3, the milk was pasteurized $\left(72^{\circ} \mathrm{C}\right.$ for 15 seconds) and chilled until reaching $36^{\circ} \mathrm{C}$. All of the material used was previously sanitized, and the processing of all of the formulations was performed under the same conditions. Initially, sodium chlorate $(10 \mathrm{~g} / \mathrm{L}$ of milk), calcium chlorate (Docina Nutrição Ltd®, Brazil) $(0.4 \mathrm{~mL} / \mathrm{L}$ of milk) and starter culture (inoculation according to the manufacturer's instructions) were added to the milk, the mixture was homogenized, and the liquid microbial chymosin coagulant (Estrella Christian Hansen ${ }^{\circledR}$, Brazil) $(0.5 \mathrm{~mL} / \mathrm{L}$ of milk) were added and the milk was homogenized again. The researchers waited 40 minutes for the coagulation to take place. Next, the curd was cut into $1 \mathrm{~cm} \mathrm{x} 1 \mathrm{~cm}$ cubes and agitated for 5 minutes with a rest period of 10 minutes. Later, the curd was separated from the whey and the cheeses were placed in their own moulds $(14.5 \mathrm{~cm}$ in diameter and $7.5 \mathrm{~cm}$ high) and maintained at $5{ }^{\circ} \mathrm{C}$. After 24 hours the cheeses were taken out of the moulds and stored at $12^{\circ} \mathrm{C}$ in BOD for 30 days to mature.

\subsection{Cheese Analysis}

The microbiological, instrumental color, moisture, and ash analyses were performed during the maturation period at 0,15 , and 30 days. The $\mathrm{pH}$ was monitored during the maturation with analyses every seven days. The acidity (\% in lactic acid) was also monitored every seven days.

\subsection{Microbiological Analysis}

Petrifilm plates (3M Company, St. Paul, MN, USA) were used in the determination of total coliforms and Escherichia coli, microbiological method 991.14 (AOAC, 2016), Salmonella sp., microbiological method 2014.01 (AOAC, 2016), and aerobic mesophiles, microbiological method 990.12 (AOAC, 2016). The analysis of Staphylococcus coagulase positive was performed according to the method proposed by Silva et al., (2017).

\subsection{Yields, Physiochemical Parameters, and Instrumental Color}

The yield was calculated based on the sum of the mass of all the ingredients used and the 
final weight of the cheese (after $24 \mathrm{~h}$ processing). For analysis of lactic acid acidity, the methodology proposed by Pereira, Silva, Costa, and Oliveira (2001) was followed. The analyses of moisture and ash were performed according to the methodology proposed by (AOAC (2012). The $\mathrm{pH}$ was controlled by a previously calibrated $\mathrm{pH}$-meter (Digital Instruments, Bresso, Italy). The aforementioned analyses were performed in duplicate.

The instrumental color was measured in triplicate using the Konica Minolta colorimeter (Konica Minolta, Tokyo, Japan) according to the International Commission on Illumination's (CIE) system $\mathrm{L} * \mathrm{a} * \mathrm{~b} *$. The values of the colors were measured under the same geometric conditions for the internal and external parts of the cheeses. The instrument was previously calibrated and the following parameters were evaluated: L: color varying from black $(0)$ to white (100); a: color varying from red (+) to green (-); and b: color varying from yellow (+) to blue (-). The results were analyzed in relation to the total difference in color $(\Delta \mathrm{E})$ between the initial and final period of maturation of the treatments, given by equation 1 .

$$
\Delta \mathrm{E}=\left[\left(\Delta \mathrm{L}^{*}\right)^{2}+\left(\Delta \mathrm{a}^{*}\right)^{2}+\left(\Delta \mathrm{b}^{*}\right)^{2}\right]^{1 / 2}
$$

\subsection{Statistical Analysis}

The results were submitted to variance analysis (ANOVA) using the GraphPad Prism 7.0 software and compared using the Tukey test at a level of $5 \%$ significance $(\mathrm{p}<0.05)$.

\section{Results and Discussion}

\subsection{Microbiological Analysis}

The evaluated treatments didn't show contamination by total coliforms, Escherichia coli, Staphylococcus coagulase positive and Salmonella sp. In relation to the count of aerobic mesophiles (Table 1), there was a significant difference for all treatments, and a lower growth of these microorganisms was observed for treatment $\mathrm{T} 1$.

Table 1. Aerobic mesophilic count (log CFU/g) of cheeses during ripening time

\begin{tabular}{cccc}
\hline Ripening time (days) & \multicolumn{3}{c}{ Treatments } \\
\hline & $\mathrm{T} 1$ & $\mathrm{~T} 2$ & $\mathrm{~T} 3$ \\
\hline Zero & $<2.00$ & $<2.00$ & $<2.00$ \\
15 & $2.70^{\mathrm{Ba}} \pm 0.11$ & $4.00^{\mathrm{Bb}} \pm 0.05$ & $4.60^{\mathrm{Bc}} \pm 0.08$ \\
30 & $2.95^{\mathrm{Ba}} \pm 0.07$ & $4.30^{\mathrm{Bb}} \pm 0.07$ & $4.84^{\mathrm{Bc}} \pm 0.06$ \\
\hline
\end{tabular}

Average \pm standard error. Means in the same column showing the same capital letters are not significantly different $(\mathrm{p}<0.05)$. Means in the same row showing the same small letters are not significantly different $(\mathrm{p}<0.05)$. T1 $=$ with pasteurized milk and with the addition of commercial lactic culture $\mathrm{K}, \mathrm{T} 2=$ with pasteurized milk and with addition of commercial lactic culture M, T3= with pasteurized milk and without addition of lactic culture.

The protective effect of the LABs is essentially due to the production of active metabolites, such as organic acids (acetic, lactic, propionic, and formic), antifungal compounds 
(phenyllactate, hydroxyphenallactate, propionate, 3-hydroxy fatty acids and cyclic dipeptides), other compounds such as fatty acids, acetoin, diacetyl, hydrogen peroxide, and bacteriocins (reuterin, nisin, reutericyclin, lacticin, pediocin, and enterocin). The objective of application of a starter culture, in addition to protection against undesirable microorganisms, is to assure uniformity in the fermentation process (Blaya et al., 2017; Favaro et al., 2015; Kelleher et al., 2015).

The increase in aerobic mesophile count in treatment T3 indicates greater proliferation of undesirable microorganisms, and, consequently, lower shelf life of the product. Therefore, the addition of the cultures Lactococcus lactis subsp. lactis and Lactococcus lactis subsp. cremoris is viable for greater preservation of Colonial cheese.

Other studies conducted in the past also verify the protective effect of the addition of starter culture in different types of cheeses. Vandera, Kakouri, Koukkou, and Samelis (2019) evaluated the addition of a freeze-dried commercial starter culture containing Streptococcus thermophilus and various strains of Lactococcus lactis in Greek Graviera cheese with 90 days of maturation, and noted the microbiological safety of this cheese during the entire storage period. Pappa, Kondyli, and Samelis (2019) analyzed the biochemical and microbiological characteristics of Kashkaval cheese during 90 days of maturation, with two treatments being evaluated: with raw milk and without the addition of a starter culture, and with pasteurized milk and with the addition of starter culture composed of Lactobacillus helveticus, Lactococcus lactis subsp. cremoris, Lactococcus lactis subsp. lactis, and Streptococcus thermophilus and noted less proliferation of undesirable microorganisms in the treatment processed with pasteurized milk and with addition of the starter culture.

The variations found for the two commercial brands in relation to acidification, $\mathrm{pH}$, and aerobic mesophiles can be attributed to the probable difference between the quantity and the proportions of bacteria making up the starter culture. According to Bekele, Hansen, Eshetu, Ipsen, and Hailu (2019), the rate of acidification of the cheeses through production of lactic acid, with consequent reduction of $\mathrm{pH}$, depends on the starter culture used.

\subsection{Yield, Moisture, and Ash}

The yield for all treatments was $20 \%$. The moisture and ash content of the cheeses are shown in Table 2.

Table 2. Changes in moisture (\%) and ashes (\%) in fresh cheese and during ripening time

\begin{tabular}{|c|c|c|c|c|c|c|c|}
\hline \multicolumn{4}{|c|}{ Moisture (\%) } & \multicolumn{4}{|c|}{ Ashes (\%) } \\
\hline $\begin{array}{l}\text { Ripening } \\
\text { time (days) }\end{array}$ & \multicolumn{3}{|c|}{ Treatments } & $\begin{array}{l}\text { Ripening } \\
\text { time (days) }\end{array}$ & \multicolumn{3}{|c|}{ Treatments } \\
\hline & $\mathrm{T} 1$ & $\mathrm{~T} 2$ & T3 & & $\mathrm{T} 1$ & $\mathrm{~T} 2$ & T3 \\
\hline Zero & $\begin{array}{c}68.66^{\mathrm{Aa}} \\
\pm 0.13\end{array}$ & $\begin{array}{c}68.04^{\mathrm{Aa}} \\
\pm 1.26\end{array}$ & $\begin{array}{c}67.83^{\mathrm{Aa}} \pm \\
0.28\end{array}$ & Zero & $\begin{array}{c}2.16^{\mathrm{Aa}} \pm \\
0.06\end{array}$ & $\begin{array}{c}2.17^{\mathrm{Aa}} \pm \\
0.06\end{array}$ & $\begin{array}{c}2.69^{\mathrm{Ab}} \pm \\
0.06\end{array}$ \\
\hline 15 & $\begin{array}{c}58.12^{\mathrm{Ba}} \\
\pm 0.89\end{array}$ & $\begin{array}{c}58.13^{\mathrm{Ba}} \\
\pm 0.90\end{array}$ & $\begin{array}{c}59.32^{\mathrm{Ba}} \pm \\
0.43\end{array}$ & 15 & $\begin{array}{c}4.28^{\mathrm{Ba}} \pm \\
0.16\end{array}$ & $\begin{array}{c}4.29^{\mathrm{Ba}} \pm \\
0.01\end{array}$ & $\begin{array}{c}4.71^{\mathrm{Ba}} \pm \\
0.08\end{array}$ \\
\hline 30 & $\begin{array}{c}42.24^{\mathrm{Ca}} \\
\pm 0.09\end{array}$ & $\begin{array}{c}42.29^{\mathrm{Ca}} \\
\pm 0.27\end{array}$ & $\begin{array}{c}42.67^{\mathrm{Ca}} \pm \\
0.10\end{array}$ & 30 & $\begin{array}{c}4.56^{\mathrm{Ba}} \pm \\
0.29\end{array}$ & $\begin{array}{c}4.54^{\mathrm{Ba}} \pm \\
0.13\end{array}$ & $\begin{array}{c}4.57^{\mathrm{Ba}} \pm \\
0.11\end{array}$ \\
\hline
\end{tabular}


Average \pm standard error $(n=2)$. Means in the same column showing the same capital letters are not significantly different $(\mathrm{p}<0.05)$. Means in the same row showing the same small letters are not significantly different $(\mathrm{p}<0.05) . \mathrm{T} 1=$ with pasteurized milk and with the addition of commercial lactic culture $\mathrm{K}, \mathrm{T} 2=$ with pasteurized milk and with addition of commercial lactic culture $\mathrm{M}, \mathrm{T} 3=$ with pasteurized milk and without addition of lactic culture.

The moisture content is directly associated with the principal characteristics relative to the type of cheese. Cheeses that go through a maturation process tend to lose water to their environment and become progressively drier. The maturation time exercises significant influence on the final moisture content. The process of removing whey, the quantity of sodium chloride added, and the size of the cheeses can also influence the final moisture content of the cheeses (El-Gawad \& Ahmed, 2011). The values referring to the moisture content in this study are presented in Table 2. At the end of the ripening period, the moisture content varied between $42.24 \%$ and $42.67 \%$, without significant difference between the samples. In the first 15 days there was an approximately $10 \%$ loss in moisture, and after 15 days of ripening, a more accentuated drop of approximately $16 \%$ was observed. Silva, Silva, Tonial, and Castro-Cislaghi (2015), after evaluating eight samples of Colonial cheese, reported a variation of 37,52 to $48,09 \%$ between them. The moisture content influences the flavour and texture of the final product, so it is a parameter to be controlled, in addition to being a determining factor for the development of desirable and undesirable bacteria alike (Sousa et al., 2014).

The cheeses are classified based on moisture content, following the patterns determined by Mercosur: low moisture (up to 35.9\%), medium moisture (36.0 to 45.9\%), high moisture (46.0 to 54.9\%), and very high moisture (greater than 55\%) (Brazil, 1996). Therefore, the Colonial cheeses in the current study present medium moisture.

The ash content suffered an increase until 15 days of maturation, and then remained stable until the end of the 30-day ripening time, without presenting statistical differences between the treatments analyzed (Table 2). The ash content found in the current study is similar to the content reported by Silva et al., (2015), with average values from $3.06 \%$ to $6.99 \%$ for samples of Colonial cheese, and by Oliveira, Bravo, and Tonial (2012), with variations from $2.77 \%$ to $5.72 \%$.

\section{$3.3 \mathrm{pH}$ and Lactic Acid Acidity}

The $\mathrm{pH}$ analysis is presented in Figure 1. It was also not possible to observe statistical differences between the samples, which could be related to the fact that the starter bacteria were not yet completely active. In the period between the first and fifteenth day of maturation, it is possible to observe an accentuated linear drop in $\mathrm{pH}$ in the treatments $\mathrm{T} 1$ and $\mathrm{T} 2$. The $\mathrm{pH}$ of treatment T3 was significantly larger than the others. In addition, a larger reduction in $\mathrm{pH}$ for treatment $\mathrm{T} 1$ compared to treatment $\mathrm{T} 2$ can be noted at the end of the maturation period. The reduction in $\mathrm{pH}$ of treatments $\mathrm{T} 1$ and $\mathrm{T} 2$ is primarily provoked by the production of lactic acid by the starter bacteria. A reduction in $\mathrm{pH}$ to values between 4.5 and 5.5 impedes the growth of undesirable microorganisms in the cheese, contributing to its preservation 
(Silva et al., 2015).



Figure 1. $\mathrm{pH}$ for cheeses during ripening time. Means among the samples in the same period showing the same letters are not significantly different $(\mathrm{p}<0.05) . \mathrm{T} 1=$ with pasteurized milk and with the addition of commercial lactic culture $\mathrm{K}, \mathrm{T} 2=$ with pasteurized milk and with addition of commercial lactic culture $\mathrm{M}, \mathrm{T} 3=$ with pasteurized milk and without addition of lactic culture

A drastic reduction in the rate of decrease in $\mathrm{pH}$ of treatments $\mathrm{T} 1$ and $\mathrm{T} 2$ can also be noted after 21 days. As maturation time passes, moisture decreases and there is an increase in alt content, carbon and nitrogen restrictions, and other adverse factors that cause diminished initial viability of the starter culture (Blaya et al., 2017; Ruggirello et al., 2018). Traditional studies with lactic acid bacteria demonstrate the reduction of these bacteria in later stages of maturation (Ruggirello, Cocolin, \& Dolci, 2016).

Silveira-Júnior et al., (2012) found pH values between 3.92 and 5.81 for six samples collected in local supermarkets during different seasons, with ripening time of 30 days. The natural bacterial constituents of unpasteurized milk metabolize lactose, producing lactic acid, reducing the $\mathrm{pH}$; with the pasteurization process, these bacteria are largely destroyed, and no reduction in $\mathrm{pH}$ is observed (treatment $\mathrm{T} 3$ ) due to insufficient lactic acid production. The addition of a starter culture to pasteurized milk is capable of recuperating the acidification of the cheese, guaranteeing the fresh, acidic taste characteristic of Colonial cheese (Bánkuti et al., 2017; Favaro et al., 2015).

Despite being unable to establish a direct relationship between $\mathrm{pH}$ and acidity, in general, it is observed that an increase in acid content is accompanied by a reduction in $\mathrm{pH}$. The values referring to the analysis of acidity (\% lactic acid) are presented in Figure 2. 


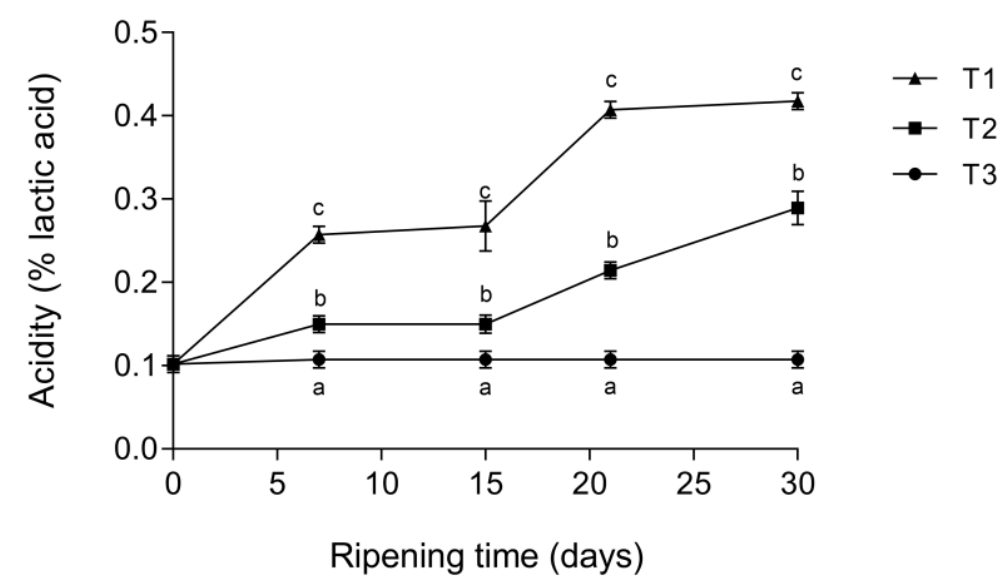

Figure 2. Acidity (\% lactic acid) for cheeses during ripening time. Means among the samples in the same period showing the same letters are not significantly different $(\mathrm{p}<0.05)$. T1= with pasteurized milk and with the addition of commercial lactic culture $\mathrm{K}, \mathrm{T} 2=$ with pasteurized milk and with addition of commercial lactic culture $\mathrm{M}, \mathrm{T} 3=$ with pasteurized milk and without addition of lactic culture

On the first day, it was not possible to note statistical difference between the treatments, as there were no changes in percent lactic acid acidity in treatment T3 (without the addition of starter culture) during the entire ripening period. Treatment $\mathrm{T} 2$ presented a small increase in acidity content during the first 15 days and a more accentuated increase after 15 days, whereas treatment $\mathrm{T} 1$ presented an accentuated linear increase during the first seven days and between 15 and 21 days, with decreased acidulant power after 21 days. The values found in the literature for acidity (\% lactic acid) as well as $\mathrm{pH}$ are quite varied, due to the differences in the way each producer adopts processing. Silva et al., (2015) found average values between 0.09 and $0.55 \%$ for Colonial cheese marketed in state of Paraná in Brazil. In another study conducted in the same region, with Colonial cheese purchased in supermarkets and free markets, was found average values between 0.24 and 1.15\% (Oliveira et al., 2012). The predictable production of lactic acid by the starter culture during processing is an important parameter for the control of texture and flavour characteristics (Favaro et al., 2015; Parente et al., 2017).

\subsection{Color}

Color is an extremely important characteristic in foods, both because it functions as an index of quality, and because it can define whether or not a product will be accepted by the consumer (Wadhwani \& McMahon, 2012). The color of the cheeses was presented in Table 3. 
Table 3. Changes in color of crust and centre of the cheeses during ripening time

\begin{tabular}{|c|c|c|c|}
\hline \multicolumn{4}{|c|}{ External } \\
\hline Ripening time (days) & $\mathrm{T} 1$ & $\mathrm{~T} 2$ & $\mathrm{~T} 3$ \\
\hline \multicolumn{4}{|c|}{ White (L) } \\
\hline Zero & $80.24^{\mathrm{Aa}} \pm 0.35$ & $81.02^{\mathrm{Aa}} \pm 0.51$ & $80.12^{\mathrm{Aa}} \pm 0.21$ \\
\hline 15 & $70.89^{\mathrm{Ba}} \pm 0.15$ & $71.01^{\mathrm{Ba}} \pm 0.50$ & $70.52^{\mathrm{Ba}} \pm 0.32$ \\
\hline 30 & $66.54^{\mathrm{Ca}} \pm 0.29$ & $66.04^{\mathrm{Ca}} \pm 0.10$ & $66.14^{\mathrm{Ca}} \pm 0.14$ \\
\hline \multicolumn{4}{|c|}{ Green (a) } \\
\hline Zero & $-9.66^{\mathrm{Aa}} \pm 0.05$ & $-9.21^{\mathrm{Ab}} \pm 0.03$ & $-9.56^{\mathrm{Aa}} \pm 0.09$ \\
\hline 15 & $-8.62^{\mathrm{Ba}} \pm 0.05$ & $-8.70^{\mathrm{Bb}} \pm 0.04$ & $-8.72^{\mathrm{Bb}} \pm 0.05$ \\
\hline 30 & $-8.15^{\mathrm{Ca}} \pm 0.05$ & $-8.16^{\mathrm{Ca}} \pm 0.05$ & $-8.13^{\mathrm{Ca}} \pm 0.05$ \\
\hline \multicolumn{4}{|c|}{ Yellow (b) } \\
\hline Zero & $34.25^{\mathrm{Aa}} \pm 0.18$ & $34.01^{\mathrm{Aa}} \pm 0.12$ & $34.03^{\mathrm{Aa}} \pm 0.15$ \\
\hline 15 & $35.25^{\mathrm{Ba}} \pm 0.27$ & $35.38^{\mathrm{Ba}} \pm 0.14$ & $35.36^{\mathrm{Ba}} \pm 0.14$ \\
\hline 30 & $36.74^{\mathrm{Ca}} \pm 0.10$ & $36.25^{\mathrm{Ca}} \pm 0.11$ & $36.34^{\mathrm{Ca}} \pm 0.21$ \\
\hline \multicolumn{4}{|c|}{ Internal } \\
\hline Ripening time (days) & $\mathrm{T} 1$ & $\mathrm{~T} 2$ & T3 \\
\hline \multicolumn{4}{|c|}{ White (L) } \\
\hline Zero & $92.49^{\mathrm{Aa}} \pm 0.57$ & $92.46^{\mathrm{Aa}} \pm 0.50$ & $93.25^{\mathrm{Aa}} \pm 0.11$ \\
\hline 15 & $91.49^{\mathrm{Aa}} \pm 0.57$ & $91.02^{\mathrm{Ba}} \pm 0.44$ & $90.23^{\mathrm{Ba}} \pm 0.55$ \\
\hline 30 & $89.18^{\mathrm{Ba}} \pm 0.14$ & $89.19^{\mathrm{Ca}} \pm 0.25$ & $89.38^{\mathrm{Ba}} \pm 0.53$ \\
\hline \multicolumn{4}{|c|}{ Green (a) } \\
\hline Zero & $-7.51^{\mathrm{Aa}} \pm 0.08$ & $-7.12^{\mathrm{Ab}} \pm 0.05$ & $-7.86^{\mathrm{Ac}} \pm 0.05$ \\
\hline 15 & $-7.55^{\mathrm{Aa}} \pm 0.09$ & $-7.63^{\mathrm{Ba}} \pm 0.08$ & $-7.51^{\mathrm{Ba}} \pm 0.06$ \\
\hline 30 & $-7.50^{\mathrm{Aa}} \pm 0.05$ & $-7.41^{\mathrm{Ca}} \pm 0.08$ & $-7.46^{\mathrm{Ca}} \pm 0.05$ \\
\hline \multicolumn{4}{|c|}{ Yellow (b) } \\
\hline Zero & $20.90^{\mathrm{Aa}} \pm 0.25$ & $19.96^{\mathrm{Ab}} \pm 0.36$ & $19.74^{\mathrm{Ab}} \pm 0.15$ \\
\hline 15 & $21.89^{\mathrm{Ba}} \pm 0.19$ & $22.57^{\mathrm{Bb}} \pm 0.11$ & $21.56^{\mathrm{Bc}} \pm 0.16$ \\
\hline 30 & $23.22^{\mathrm{Ca}} \pm 0.11$ & $23.39^{\mathrm{Ca}} \pm 0.18$ & $23.32^{\mathrm{Ca}} \pm 0.16$ \\
\hline
\end{tabular}

Average \pm standard error $(n=3)$. Means in the same column showing the same capital letters are not significantly different $(\mathrm{p}<0.05)$. Means in the same row showing the same small letters are not significantly different $(\mathrm{p}<0.05) . \mathrm{T} 1=$ with pasteurized milk and with the addition of commercial lactic culture $\mathrm{K}, \mathrm{T} 2=$ with pasteurized milk and with addition of 
commercial lactic culture $\mathrm{M}, \mathrm{T} 3=$ with pasteurized milk and without addition of lactic culture.

The brightness of cheeses over the period of maturation diminishes significantly $(p<0.05)$ for all the samples, both internally and externally. For the external crust, lower brightness is noted as compared to the internal part, due to the greater exposure of the surface of the cheese to the environment, resulting in greater loss of water and greater gas exchanges with the external atmosphere. The parameter (a), when negative, indicates tendency toward the color green; over the ripening period, a greater tendency toward this coloration is noted for all treatments, both externally and internally, with greater tendency for the external crust. For yellow coloration (parameter b), an increase in tonality for the samples at the end of 30 days is observed, principally for the crust, without statistical difference between the samples. This tendency towards yellow coloration is justified principally by the carotenoids present in the milk, obtained from the animal diet, that become more concentrated with the dehydration process (McDermott et al., 2016). Other studies with cheeses have also verified the tendency toward green and yellow colorations and decreased brightness with the increase of storage time (Youssef, El-Sayed, El-Sayed, Salama, \& Dufresne, 2016; Zhong, Cavender, \& Zhao, 2014).

\section{Conclusion}

The addition of the culture Lactococcus lactis subsp. lactis and Lactococcus lactis subsp. cremoris was capable of inhibiting the growth of aerobic mesophiles, reducing the $\mathrm{pH}$, and increasing the acidity (\% lactic acid) in Colonial cheeses with pasteurized milk, resulting in a safer product with characteristics similar to those of cheeses produced with unpasteurized milk. The addition of the culture did not exert influence over the parameters of yield, moisture, ash, or instrumental color. The commercial brands used show statistical difference for aerobic mesophiles count, $\mathrm{pH}$, and lactic acid acidity; this difference is attributed to the difference in concentration of microorganisms present in the two brands.

\section{Acknowledgement}

We thank Conselho Nacional de Desenvolvimento Científico e Tecnológico (CNPQ) for the financial support (process number 130827/2017-7), and Capes.

\section{References}

AOAC. (2012). Official Methods of Analysis of AOAC International (19th ed.). Arlington: Association of Official Analytical Chemists.

AOAC. (2016). Official Methods of Analysis of AOAC International. Microbiological Methods (20th ed.). Arlington: Association of Official Analytical Chemists.

Bánkuti, F. I., Madrona, G. S., Pozza, M. S. S., Bánkuti, S. M. S., Santos, S. S., \& Ressutte, J. (2017). Potencialidades tecnológicas e qualidade da cadeia produtiva do queijo colonial na região Sul do Brasil: uma revisão. FTT Journal of Engineering and Business, 2, 50-64.

Bekele, B., Hansen, E. B., Eshetu, M., Ipsen, R., \& Hailu, Y. (2019). Effect of starter cultures 
on properties of soft white cheese made from camel (Camelus dromedarius) milk. Journal of Dairy Science, 102(2), 1108-1115. https://doi.org/10.3168/jds.2018-15084

Blaya, J., Barzideh, Z., \& LaPointe, G. (2017). Interaction of starter cultures and nonstarter lactic acid bacteria in the cheese environment. Journal of Dairy Science, 101, 1-19. https://doi.org/10.3168/jds.2017-13345

Brasil. (1996). Diário Oficial da União. Portaria no 146 de 7 de março de 1996. Aprova os regulamentos técnicos de identidade e qualidade dos produtos lácteos.

El-Gawad, M. A. M. A., \& Ahmed, N. S. (2011). Cheese yield as affected some parameters review. Acta Scientiarum Polonorum, 10(2), 131-153.

Fava, L. W., Hernandes, J. F. M., Pinto, A. T., \& Schmidt, V. (2012). Características de queijos artesanais tipo colonial comercializados em uma feira agropecuária. Acta Scientiae Veterinariae, 40(4), 1-6.

Favaro, L., Barretto Penna, A. L., \& Todorov, S. D. (2015). Bacteriocinogenic LAB from cheeses - Application in biopreservation? Trends in Food Science and Technology, 41(1), 37-48. https://doi.org/10.1016/j.tifs.2014.09.001

Fernández, E., Alegría, Á., Delgado, S., Martín, M. C., \& Mayo, B. (2011). Comparative phenotypic and molecular genetic profiling of wild Lactococcus lactis subsp. lactis strains of the L. lactis subsp. lactis and L. lactis subsp. cremoris genotypes, isolated from starter-free cheeses made of raw milk. Applied and Environmental Microbiology, 77(15), 5324-5335. https://doi.org/10.1128/AEM.02991-10

Furtado, M. M., \& Lourenço, J. P. M. (1994). Tecnologia de queijos: manual técnico para produção industrial de queijos. São Paulo: Dimepar.

Kelleher, P., Murphy, J., Mahony, J., \& Sinderen, D. van. (2015). Next-generation sequencing as an approach to dairy starter selection. Dairy Science and Technology, 95(5), 545-568. https://doi.org/10.1007/s13594-015-0227-4

Masood, M. I., Qadir, M. I., Shirazi, J. H., \& Khan, I. U. (2011). Beneficial effects of lactic acid bacteria on human beings. Critical Reviews in Microbiology, 37(1), 91-98. https://doi.org/10.3109/1040841X.2010.536522

McDermott, A., Visentin, G., McParland, S., Berry, D. P., Fenelon, M. A., \& De Marchi, M. (2016). Effectiveness of mid-infrared spectroscopy to predict the color of bovine milk and the relationship between milk color and traditional milk quality traits. Journal of Dairy Science, 99(5), 1-7. https://doi.org/10.3168/jds.2015-10424

Oliveira, D. F., Bravo, C. E. C., \& Tonial, I. B. (2012). Sazonalidade como fator interferente na composição físico-química e avaliação microbiológica de queijos coloniais. Arquivo Brasileiro Medicina Vterinaria e Zootecnoogia, 64(2), 521-523. https://doi.org/10.1590/S0102-09352012000200040

Pappa, E. C., Kondyli, E., \& Samelis, J. (2019). Microbiological and biochemical 
characteristics of Kashkaval cheese produced using pasteurised or raw milk. International Dairy Journal, 89, 60-67. https://doi.org/10.1016/j.idairyj.2018.08.011

Parente, E., Cogan, T. M., \& Powell, I. B. (2017). Starter Cultures: General Aspects. In Chemistry, Physics and Microbiology (4th ed.). Australia: Elsevier. https://doi.org/10.1016/S1874-558X(04)80065-4

Pereira, D. B. C., Silva, P. H. F., Costa, L. C. G., \& Oliveira, L. L. (2001). Físico-química do leite e derivados: métodos analíticos. Juiz de Fora: EPAMIG.

Ruggirello, M., Cocolin, L., \& Dolci, P. (2016). Fate of Lactococcus lactis starter cultures during late ripening in cheese models. Food Microbiology, 59, 112-118. https://doi.org/10.1016/j.fm.2016.05.001

Ruggirello, M., Giordano, M., Bertolino, M., Ferrocino, I., Cocolin, L., \& Dolci, P. (2018). Study of Lactococcus lactis during advanced ripening stages of model cheeses characterized by GC-MS. Food Microbiology, 74, 132-142. https://doi.org/10.1016/j.fm.2018.03.012

Silva, F., Silva, G., Tonial, I. B., \& Castro-Cislaghi, F. P. (2015). Qualidade microbiológica e físico-química de queijos coloniais com e sem inspeção, comercializados no sudoeste do Paraná. Boletim Centro de Pesquisa de Processamento de Alimentos, 33(2), 32-42. https://doi.org/10.5380/cep.v33i2.46230

Silva, N., Junqueira, V. C. A., Silveira, N. F. A., Taniwaki, M. H., Gomes, R. A. R., \& Okazaki, M. M. (2017). Manual de métodos de análise microbiológica de alimentos e água (5th ed.). São Paulo: Blucher.

Silveira-Júnior, J. F., Oliveira, D. F., Braghini, F., Loss, E. M. S., Bravo, C. E. C., \& Tonial, I. B. (2012). Caracterização físico-química de queijos coloniais produzidos em diferentes épocas do ano. Revista Do Instituto de Laticínios Candido Tostes, 386(67), 67-80. https://doi.org/10.5935/2238-6416.20120038

Sousa, A. Z. B., Abrantes, M. R., Sakamoto, S. M., Silva, J. B. A., Lima, P. O., Lima, R. N., ... Passos, Y. D. B. (2014). Aspectos físico-químicos e microbiológicos do queijo tipo coalho comercializado em estados do nordeste do Brasil. Arquivos Do Instituto Biológico, 81(1), 30-35. https://doi.org/10.1590/S1808-16572014000100006

Vandera, E., Kakouri, A., Koukkou, A. I., \& Samelis, J. (2019). Major ecological shifts within the dominant nonstarter lactic acid bacteria in mature Greek Graviera cheese as affected by the starter culture type. International Journal of Food Microbiology, 290, 15-26. https://doi.org/10.1016/j.ijfoodmicro.2018.09.014

Vázquez-Velázquez, R., Salvador-Figueroa, M., Adriano-Anaya, L., Degyves-Córdova, G., \& Vázquez-Ovando, A. (2018). Use of starter culture of native lactic acid bacteria for producing an artisanal Mexican cheese safe and sensory acceptable. CYTA - Journal of Food, 16(1), 460-468. https://doi.org/10.1080/19476337.2017.1420694

Wadhwani, R., \& McMahon, D. J. (2012). Color of low-fat cheese influences flavor perception and consumer liking. Journal of Dairy Science, 95(5), 2336-2346. 
https://doi.org/10.3168/jds.2011-5142

Youssef, A. M., El-Sayed, S. M., El-Sayed, H. S., Salama, H. H., \& Dufresne, A. (2016). Enhancement of Egyptian soft white cheese shelf life using a novel chitosan/carboxymethyl cellulose/zinc oxide bionanocomposite film. Carbohydrate Polymers, 151, 9-19. https://doi.org/10.1016/j.carbpol.2016.05.023

Zhong, Y., Cavender, G., \& Zhao, Y. (2014). Investigation of different coating application methods on the performance of edible coatings on Mozzarella cheese. LWT - Food Science and Technology, 56, 1-8. https://doi.org/10.1016/j.lwt.2013.11.006

\section{Copyright Disclaimer}

Copyright for this article is retained by the author(s), with first publication rights granted to the journal.

This is an open-access article distributed under the terms and conditions of the Creative Commons Attribution license (http://creativecommons.org/licenses/by/4.0/). 